\section{Kidney \\ Blood Pressure \\ Research}

Original Paper

\title{
Regulation of CIC-2 Activity by SPAK and OSR1
}

\author{
Jamshed Warsi Zohreh Hosseinzadeh Bernat Elvira Rosi Bissinger \\ Ekaterina Shumilina Florian Lang
}

Department of Physiology I, University of Tübingen, 72076 Tübingen, Germany

Key Words

$\mathrm{Cl}^{-}$channels $•$ Cell volume regulation $• \mathrm{WNK} \cdot$ Voltage clamp • Oocytes

\begin{abstract}
Background/Aims: SPAK (SPS1-related proline/alanine-rich kinase) and OSR1 (oxidative stress-responsive kinase 1) are powerful regulators of diverse transport processes. Both kinases are activated by cell shrinkage and participate in stimulation of regulatory cell volume increase (RVI). Execution of RVI involves inhibition of $\mathrm{Cl}^{-}$channels. The present study explored whether SPAK and/or OSR1 regulate the activity of the $\mathrm{Cl}^{-}$channel $\mathrm{ClC}-2$. Methods: To this end, $\mathrm{ClC}-2$ was expressed in Xenopus laevis oocytes with or without additional expression of wild type SPAK, constitutively active SPAK ${ }^{\mathrm{T} 33 E}$, WNK1 insensitive inactive SPAK ${ }^{\mathrm{T} 233 \mathrm{~A}}$, catalytically inactive SPAK ${ }^{\text {D212A }}$, wild type OSR1, constitutively active OSR1 $1^{\text {T185E }}$, WNK1 insensitive inactive OSR1 ${ }^{\text {T185A }}$, and catalytically inactive OSR1 $1^{\mathrm{D} 164 \mathrm{~A}}$. $\mathrm{Cl}^{-}$channel activity was determined by dual electrode voltage clamp. Results: Expression of $\mathrm{ClC}-2$ was followed by the appearance of a conductance $\left(\mathrm{G}_{\mathrm{C}}\right)$, which was significantly decreased following coexpression of wild-type SPAK, SPAK ${ }^{\mathrm{T} 233 E}$, wild type OSR1 or OSR1 ${ }^{\text {T185E, }}$, but not by coexpression of SPAK ${ }^{T 233 A}$, SPAK ${ }^{\mathrm{D212A}}$, OSR1 ${ }^{\mathrm{T1} 85 \mathrm{~A}}$, or OSR1 ${ }^{\text {D164A. }}$. Inhibition of $\mathrm{ClC}-2$ insertion by brefeldin $A(5 \mu \mathrm{M})$ resulted in a decline of $G_{C I}$ which was similar in the absence and presence of SPAK or OSR1, suggesting that SPAK and OSR1 did not accelerate the retrieval of $\mathrm{ClC}-2$ protein from the cell membrane. Conclusion: SPAK and OSR1 are powerful negative regulators of the cell volume regulatory $\mathrm{Cl}^{-}$channel $\mathrm{ClC}-2$.
\end{abstract}

Copyright (C) 2014 S. Karger AG, Basel

\section{Introduction}

SPAK (SPS1-related proline/alanine-rich kinase) [1-3] and OSR1 (oxidative stressresponsive kinase 1) $[4,5]$ are related kinases involved in the regulation of ion transport and thus blood pressure. The activity of SPAK and OSR1 is controlled by WNK (with-no$\mathrm{K}$ [Lys]) kinases [1, 6-9], which are again involved in the regulation of ion transport and 


\section{Kidney \\ Blood Pressure Research}

blood pressure [10-14]. Along those lines, mutations of genes encoding WNK kinases may lead to hypertension and hyperkalaemia $[7,8,15,16]$. Carriers upregulated by SPAK and OSR1 include the $\mathrm{Na}^{+}-\mathrm{Cl}^{-}$cotransporter and the $\mathrm{Na}^{+}, \mathrm{K}^{+}, 2 \mathrm{Cl}^{-}$cotransporter $[4-6,9,10,17-25]$. Moreover, OSR1 and/or SPAK may modify further transport systems, including $\mathrm{Na}^{+}$coupled glucose transporter SGLT1 [26], $\mathrm{Na}^{+}$coupled phosphate transport [27, 28], and $\mathrm{Na}^{+} / \mathrm{H}^{+}$ exchanger [29]. SPAK and OSR1 are activated by cell shrinkage and the kinases are involved in regulatory cell volume decrease [30]. Cell volume regulation is in part accomplished by $\mathrm{Cl}^{-}$ channels [31-33] including the ubiquitously expressed inwardly rectifying $\mathrm{Cl}^{-}$channel $\mathrm{ClC}-2$ $[33,34]$. Cell shrinkage leads to inhibition of $\mathrm{Cl}^{-}$channels thus curtailing cellular $\mathrm{Cl}^{-}$loss [35, 36].

The present study explored whether SPAK and/or OSR1 modify the activity of the $\mathrm{Cl}^{-}$ channel ClC-2. To this end, cRNA encoding ClC-2 was injected into Xenopus laevis oocytes with or without cRNA encoding wild-type SPAK, WNK1 insensitive SPAK ${ }^{\mathrm{T} 233 \mathrm{~A}}$, constitutively active SPAK ${ }^{\mathrm{T} 233 \mathrm{E}}$, catalytically inactive SPAK ${ }^{\mathrm{D} 212 \mathrm{~A}}$, wild-type OSR1, WNK1 insensitive inactive OSR $1^{\mathrm{T} 185 \mathrm{~A}}$, constitutively active OSR ${ }^{\mathrm{T} 185 \mathrm{E}}$, and catalytically inactive OSR $1^{\mathrm{D} 164 \mathrm{~A}}$ [9]. ClC-2 activity in those oocytes was estimated from cell membrane conductance, which was quantified by dual electrode voltage clamp.

\section{Materials and Methods}

\section{Constructs}

Constructs encoding wild-type human ClC-2 [37, 38], wild-type SPAK, WNK1 insensitive inactive SPAK ${ }^{\mathrm{T} 233 \mathrm{~A}}$, constitutively active SPAK ${ }^{\mathrm{T} 233 \mathrm{E}}$, and catalytically inactive $\mathrm{SPAK}^{\mathrm{D} 212 \mathrm{~A}}$, wild-type OSR1, WNK1 insensitive inactive OSR1 ${ }^{\mathrm{T185A}}$, constitutively active OSR ${ }^{\mathrm{T} 185 \mathrm{E}}$, and catalytically inactive OSR1 ${ }^{\mathrm{D} 164 \mathrm{~A}}$ [9] were used for generation of cRNA as described previously [39, 40]. All mutants were kindly provided by Dario Alessi.

Voltage clamp in Xenopus laevis oocytes

Xenopus laevis oocytes were prepared as previously described [41]. Where not indicated otherwise, 15 ng cRNA encoding ClC-2 were injected on the first day and 10 ng cRNA encoding SPAK, SPAK ${ }^{\mathrm{T} 233 \mathrm{~A}}$, $\mathrm{SPAK}^{\mathrm{T} 233 \mathrm{E}}, \mathrm{SPAK}^{\mathrm{D} 212 \mathrm{~A}}$, OSR1, OSR1 $1^{\mathrm{T} 185 \mathrm{~A}}$, OSR1 $1^{\mathrm{T} 185 \mathrm{E}}$, or OSR1 ${ }^{\mathrm{D} 164 \mathrm{~A}}$ were injected on the second day or the same day after preparation of the oocytes $[27,42]$. The oocytes were maintained at $17^{\circ} \mathrm{C}$ in ND96-A solution containing (in mM): $88.5 \mathrm{NaCl}, 2 \mathrm{KCl}, 1 \mathrm{MgC} 1_{2}, 1.8 \mathrm{CaC}_{2}, 2.5 \mathrm{NaOH} 5 \mathrm{HEPES}, 5$ sodium pyruvate $\left(\mathrm{C}_{3} \mathrm{H}_{3} \mathrm{NaO}_{3}\right)$ pH 7.4, gentamycin $(100 \mathrm{mg} / \mathrm{l})$, tetracycline $(50 \mathrm{mg} / \mathrm{l})$, ciprofloxacin $(1.6 \mathrm{mg} / \mathrm{l})$, and theophiline $(90 \mathrm{mg} / \mathrm{l})$ [43]. Where indicated, brefeldin A (5 $\mu \mathrm{M})$ was added to the respective solutions [44]. The voltage clamp experiments were performed at room temperature 3 days after injection. Two-electrode voltage-clamp recordings [45] were obtained utilizing a pulse protocol of $10 \mathrm{~s}$ pulses from $-140 \mathrm{mV}$ to $+40 \mathrm{mV}$ in $20 \mathrm{mV}$ increments. The intermediate holding voltage was $-60 \mathrm{mV}$. The data were filtered at $2 \mathrm{kHz}$, and recorded with a DigiData 1322A converter and the pClamp 9.2 software for data acquisition and analysis (Axon Instruments, USA) [46]. The superfusate (ND96) contained (in mM): $93.5 \mathrm{NaCl}, 2 \mathrm{KCl}, 1.8 \mathrm{CaCl}_{2}, 1 \mathrm{MgCl}_{2} 2.5 \mathrm{NaOH}$ and 5 HEPES, $\mathrm{pH}$ 7.4. The flow rate of the superfusion was approx. $20 \mathrm{ml} / \mathrm{min}$, and a complete exchange of the bath solution was reached within about $10 \mathrm{~s}[47,48]$.

\section{Statistical analysis}

Data are provided as means \pm SEM, $\mathrm{n}$ represents the number of oocytes. All voltage clamp experiments were repeated with at least 3 batches of oocytes; in all repetitions qualitatively similar data were obtained. Data were tested for significance using ANOVA. Results with $\mathrm{p}<0.05$ were considered statistically significant.

\section{Results}

The present study explored whether SPAK (STE20/SPS1-related proline/alanine-rich kinase) and OSR1 (oxidative stress-responsive kinase 1) influence the activity of ClC-2 $\mathrm{Cl}^{-}$ channels. To this end cRNA encoding ClC-2 was injected into Xenopus laevis oocytes with 


\section{Kidney \\ Blood Pressure \\ Research}

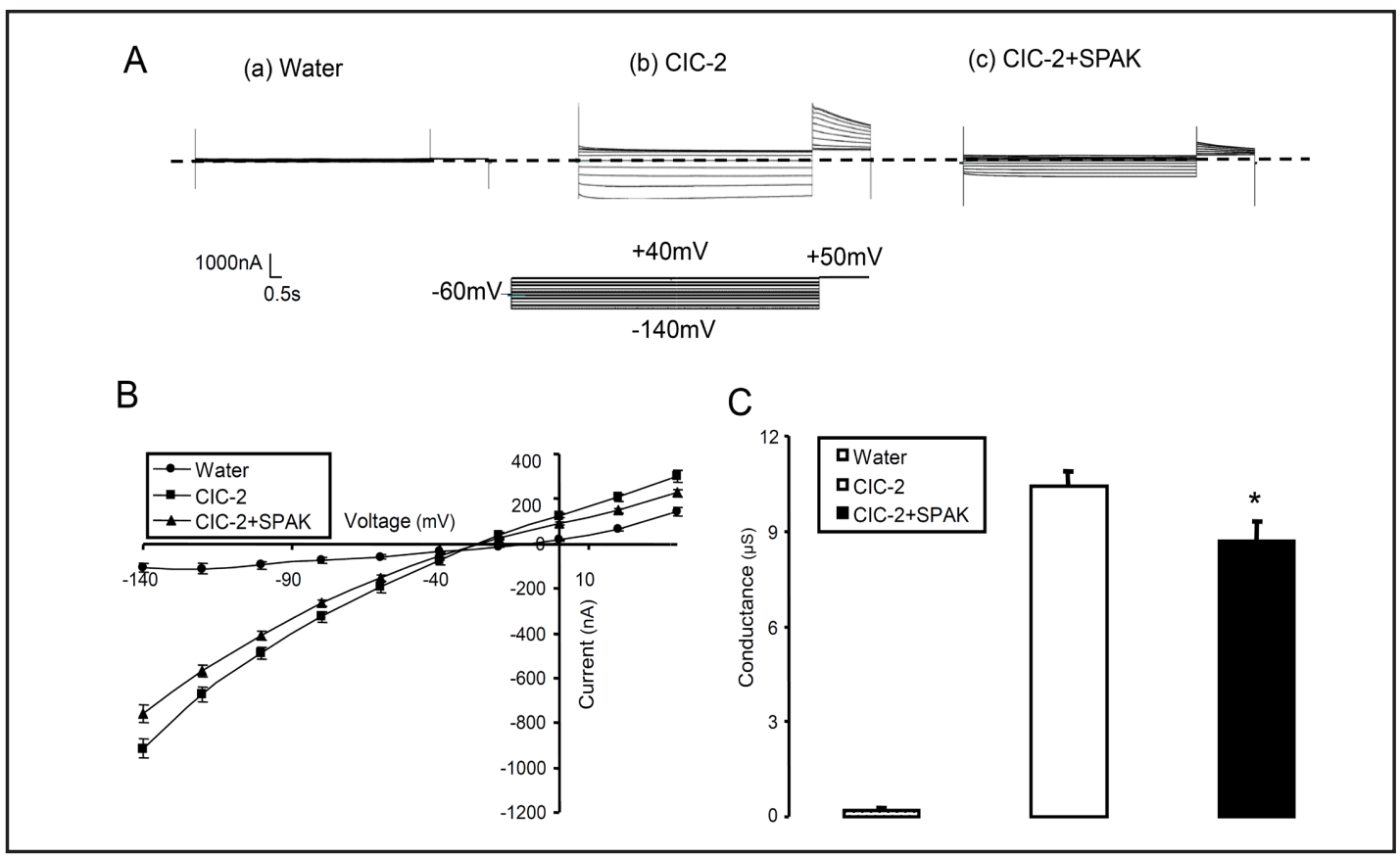

Fig. 1. Effect of wild-type SPAK coexpression on $\mathrm{Cl}^{-}$conductance in $\mathrm{ClC}$-2-expressing Xenopus laevis oocytes. A: Representative original tracings showing currents in Xenopus laevis oocytes injected with DEPC water (a), as well as in oocytes expressing ClC-2 without (b) or with (c) additional coexpression of wild type SPAK. B: Arithmetic means \pm SEM ( $n=10-31)$ of the current (I) as a function of the potential difference across the cell membrane (V) in Xenopus laevis oocytes injected with water (circles), expressing ClC-2 alone (squares) or expressing ClC-2 together with wild type SPAK (triangles). C: Arithmetic means \pm SEM ( $n=10-31)$ of the conductance calculated by linear fit of I/V-curves shown in B between $-140 \mathrm{mV}$ and $-80 \mathrm{mV}$ in Xenopus laevis oocytes injected with water (dotted bar), expressing ClC-2 alone (white bar) or expressing ClC-2 together with wild type SPAK (black bar). ${ }^{*}(\mathrm{p}<0.05)$ indicates statistically significant difference to expression of ClC-2 alone.

or without additional injection of cRNA encoding SPAK or OSR1 and the cell membrane conductance determined utilizing dual-electrode voltage-clamp. In water injected oocytes the cell membrane conductance was low (Fig.1). As illustrated in Fig. 1, expression of ClC2 resulted in a marked increase of cell membrane conductance. As shown in Fig. 1, the cell membrane conductance of $\mathrm{ClC}-2$ expressing Xenopus laevis oocytes was significantly decreased by additional expression of wild type SPAK. Similarly, coexpression of OSR1 was followed by a significant decrease of cell membrane conductance in ClC-2 expressing Xenopus laevis oocytes (Fig. 2).

The effect of wild type SPAK was mimicked by the constitutively active mutant SPAK ${ }^{\text {T233E }}$. Accordingly, the conductance was significantly lower in Xenopus laevis oocytes expressing ClC-2 together with SPAK ${ }^{\mathrm{T} 233 \mathrm{E}}$ than in Xenopus laevis oocytes expressing ClC-2 alone (Fig. 3). In contrast, ClC-2 activity was not significantly modified by WNK1 insensitive inactive SPAK ${ }^{\text {T233A }}$ or by catalytically inactive $\operatorname{SPAK}^{\mathrm{D} 212 \mathrm{~A}}$ (Fig. 3).

The effect of wild type OSR1 was mimicked by the constitutively active mutant OSR1 $1^{\mathrm{T} 185 \mathrm{E}}$. Again, coexpression of OSR1 ${ }^{\mathrm{T} 185 \mathrm{E}}$ significantly decreased cell membrane conductance of ClC-2 expressing Xenopus laevis oocytes and the conductance was significantly lower in Xenopus laevis oocytes expressing ClC-2 together with OSR1 ${ }^{\mathrm{T} 185 \mathrm{E}}$ than in Xenopus laevis oocytes expressing ClC-2 alone (Fig. 4). In contrast, ClC-2 activity was not significantly modified by coexpression of WNK1 insensitive inactive OSR $1^{\mathrm{T} 185 \mathrm{~A}}$ or by coexpression of catalytically inactive OSR1 ${ }^{\text {D164A }}$ (Fig. 4). 


\section{Kidney \\ Blood Pressure Research}

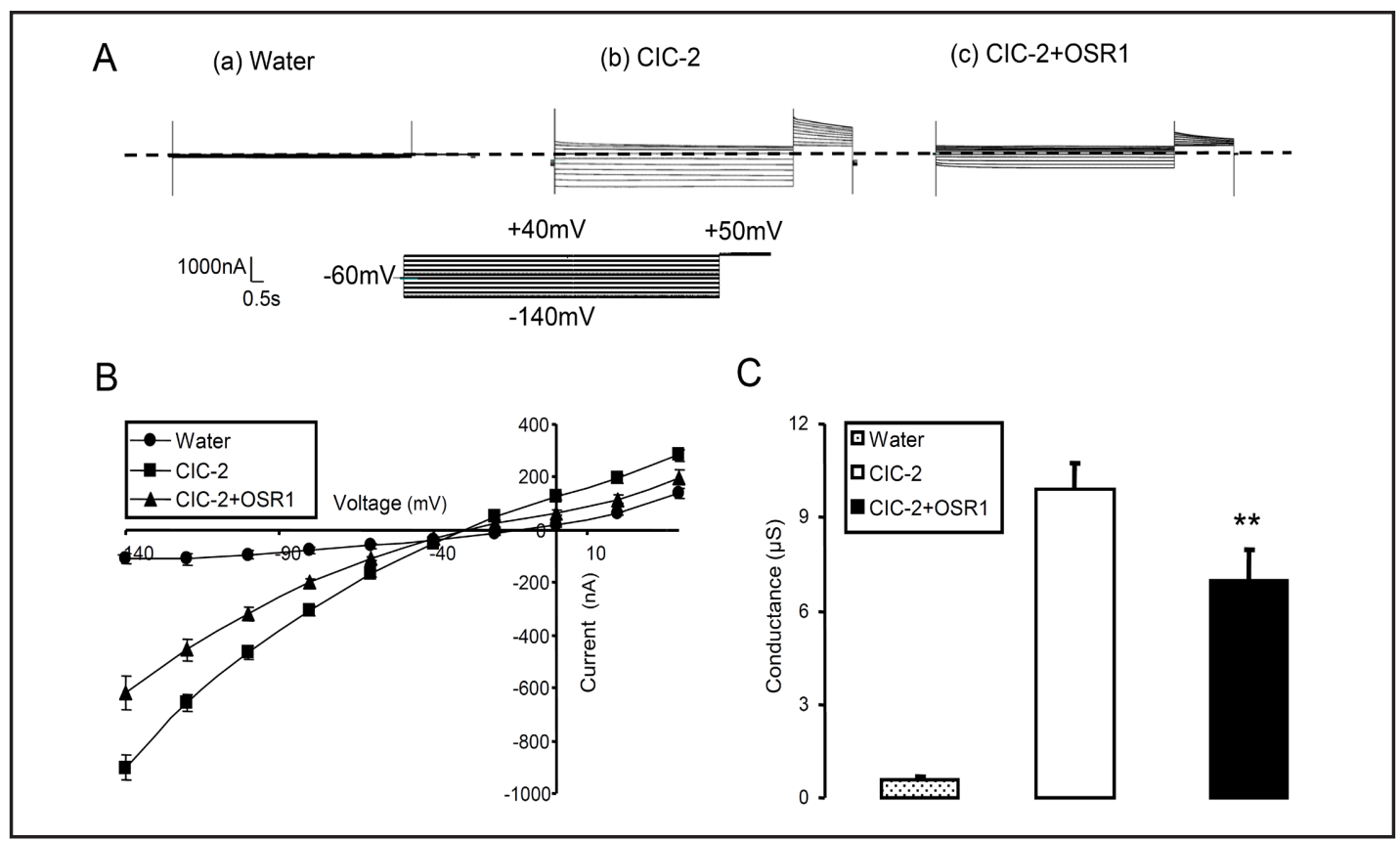

Fig. 2. Effect of wild-type OSR1 coexpression on $\mathrm{Cl}^{-}$conductance in $\mathrm{ClC}$-2-expressing Xenopus laevis oocytes. A: Representative original tracings showing currents in Xenopus laevis oocytes injected with DEPC water (a), as well as in oocytes expressing ClC-2 without (b) or with (c) additional coexpression of wild type OSR1. B: Arithmetic means \pm SEM $(n=16-34)$ of the current (I) as a function of the potential difference across the cell membrane (V) in Xenopus laevis oocytes injected with water (circles), expressing ClC-2 alone (squares) or expressing ClC-2 together with wild type OSR1 (triangles). C: Arithmetic means \pm SEM ( $n=16-34$ ) of the conductance calculated by linear fit of I/V-curves shown in B between -140 mV and -80 mV in Xenopus laevis oocytes injected with water (dotted bar), expressing ClC-2 alone (white bar) or expressing ClC-2 together with wild type OSR1 (black bar). ${ }^{* *}(\mathrm{p}<0.01)$ indicates statistically significant difference to expression of ClC-2 alone.

At least in theory, SPAK and OSR1 could have decreased ClC-2 channel activity by accelerating the retrieval of channel protein from the cell membrane. In order to test this possibility, Xenopus laevis oocytes expressing ClC-2 with or without SPAK were treated with $5 \mu \mathrm{M}$ brefeldin $\mathrm{A}$, a substance disrupting insertion of new channel protein into the cell membrane. As illustrated in Fig. 5A, the decline of conductance in the presence of brefeldin A was similar in oocytes expressing ClC-2 together with SPAK and oocytes expressing CIC-2 alone. The same observations were made in Xenopus laevis oocytes expressing ClC-2 with or without OSR1. As shown in Fig. 5B, the decline of conductance in the presence of brefeldin A was again similar in oocytes expressing ClC-2 together with OSR1 and in oocytes expressing ClC- 2 alone. Thus, neither SPAK nor OSR1 accelerated the retrieval of channel protein from the cell membrane.

\section{Discussion}

The present study reveals that the WNK-dependent STE20/SPS1-related proline/ alanine-rich kinase SPAK and the oxidative stress-responsive kinase OSR1 are both powerful negative regulators of the ubiquitously expressed $\mathrm{Cl}^{-}$channel $\mathrm{ClC}-2$. The kinases do not significantly modify the decline of the current following inhibition of channel insertion into the cell membrane indicating that the kinases are not effective by accelerating the clearance 


\section{Kidney Blood Pressure Research}

A

(a) Water

(b) $\mathrm{CIC}-2$

(c) CIC-2+SPAK ${ }^{\mathrm{T} 233 \mathrm{E}}$

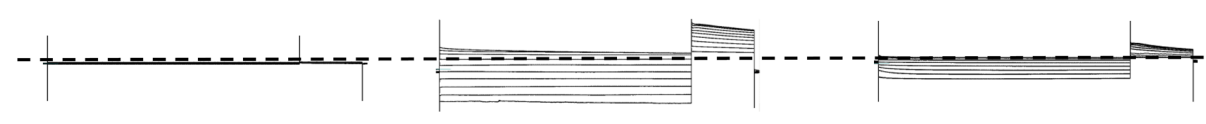

(d) CIC-2+SPAK ${ }^{\mathrm{T} 233 \mathrm{~A}}$

(e) CIC-2+SPAK ${ }^{\mathrm{D} 212 \mathrm{~A}}$
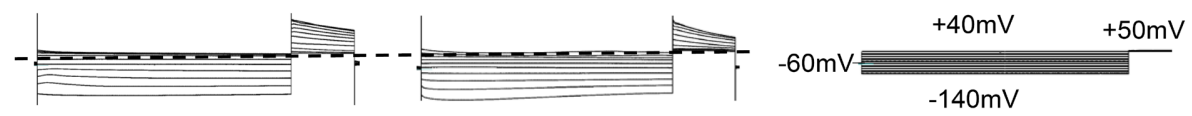

B

C
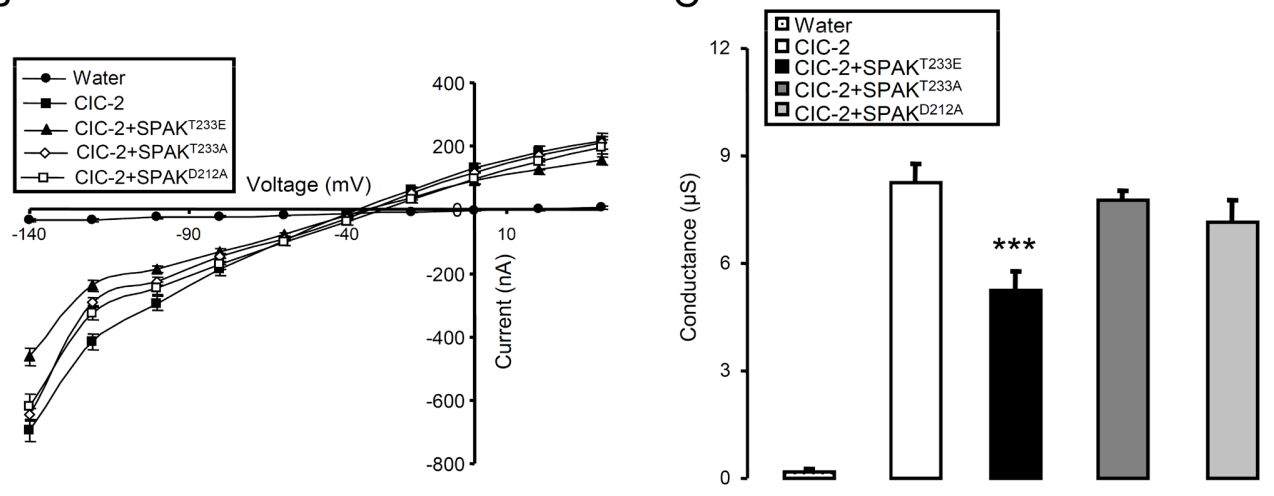

Fig. 3. Effect of expression of constitutively active $S P A K^{\mathrm{T} 233 \mathrm{E}}$, inactive $\mathrm{SPAK}^{\mathrm{T} 233 \mathrm{~A}}$ and catalytically inactive $\mathrm{SPAK}^{\mathrm{D} 212 \mathrm{~A}}$ on $\mathrm{Cl}^{-}$conductance in $\mathrm{ClC}$-2-expressing Xenopus laevis oocytes. A: Representative original tracings showing currents in Xenopus laevis oocytes injected with DEPC water (a), as well as in oocytes expressing ClC-2 without (b) or with additional coexpression of constitutively active SPAK ${ }^{\mathrm{T} 233 \mathrm{E}}$ (c), inactive SPAK ${ }^{\mathrm{T} 233 \mathrm{~A}}$ (d) and catalytically inactive $\operatorname{SPAK}^{\mathrm{D} 212 \mathrm{~A}}(\mathrm{e})$. B: Arithmetic means \pm SEM $(\mathrm{n}=18-25)$ of the current (I) as a function of the potential difference across the cell membrane (V) in Xenopus laevis oocytes injected with water (black circles), expressing $\mathrm{ClC}-2$ alone (black squares) or expressing $\mathrm{ClC}-2$ together with constitutively active $\mathrm{SPAK}^{\mathrm{T} 233 \mathrm{E}}$ (black triangles), inactive $\mathrm{SPAK}^{\mathrm{T} 233 \mathrm{~A}}$ (white diamonds) and catalytically inactive SPAK ${ }^{\mathrm{D} 212 \mathrm{~A}}$ (white squares). C: Arithmetic means \pm SEM $(n=18-25)$ of the conductance calculated by linear fit of I/Vcurves shown in B between $-140 \mathrm{mV}$ and $-80 \mathrm{mV}$ in Xenopus laevis oocytes injected with water (dotted bar), expressing ClC-2 alone (white bar) or expressing ClC-2 together with constitutively active SPAK ${ }^{\mathrm{T} 233 \mathrm{E}}$ (black bar), inactive SPAK ${ }^{\mathrm{T} 233 \mathrm{~A}}$ (dark grey bar) and catalytically inactive $\operatorname{SPAK}^{\mathrm{D} 212 \mathrm{~A}}$ (light grey bar). ${ }^{* * *}(\mathrm{p}<0.001)$ indicates statistically significant difference to expression of $\mathrm{ClC}-2$ alone.

of channel protein from the cell membrane. ClC-2 downregulation is observed following coexpression of wild type SPAK and OSR1 as well as constitutively active SPAK ${ }^{\mathrm{T} 233 \mathrm{E}}$ and OSR1 ${ }^{\mathrm{T} 185 \mathrm{E}}$ but not following coexpression of WNK1 insensitive inactive SPAK ${ }^{\mathrm{T} 233 \mathrm{~A}}$ and OSR1 ${ }^{\mathrm{T} 185 \mathrm{~A}}$ or catalytically inactive SPAK ${ }^{\mathrm{D} 212 \mathrm{~A}}$ or OSR $1^{\mathrm{D} 164 \mathrm{~A}}$. Accordingly, kinase activity is required for the observed effects.

The effect of SPAK/OSR1 on ClC-2 may participate in the regulation of cell volume, as inhibition of $\mathrm{Cl}^{-}$channels interferes with $\mathrm{Cl}^{-}$exit thus leading to hyperpolarization of the cell membrane with subsequent decrease of $\mathrm{K}^{+}$exit. The inhibition of $\mathrm{KCl}$ exit prevents further loss of osmotically obliged water. Cell shrinkage is well known to inhibit cell volume regulatory $\mathrm{Cl}^{-}$ channels [35, 36]. ClC-2 has been shown to be regulated by cell volume [32] and down regulation of ClC-2 could well participate in the SPAK/OSR1 sensitive regulation of cell volume.

$\mathrm{Cl}^{-}$channels participate in the regulation of cell proliferation [49]. Activation of $\mathrm{Cl}^{-}$ channels fosters cell shrinkage, a prerequisite for triggering oscillations of cytosolic $\mathrm{Ca}^{2+}$ activity in proliferating cells [50]. 


\section{Kidney \\ Blood Pressure Research}

A

(a) Water

(b) $\mathrm{CIC}-2$

(c) CIC-2+OSR1 $1^{\mathrm{T} 185 \mathrm{E}}$

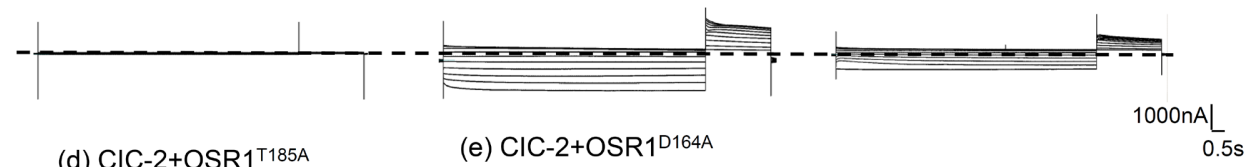

(d) CIC-2+OSR1T185A

(e) CIC-2+OSR1D164A

$0.5 \mathrm{~s}$

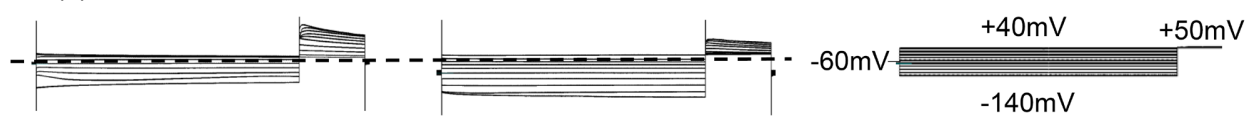

B

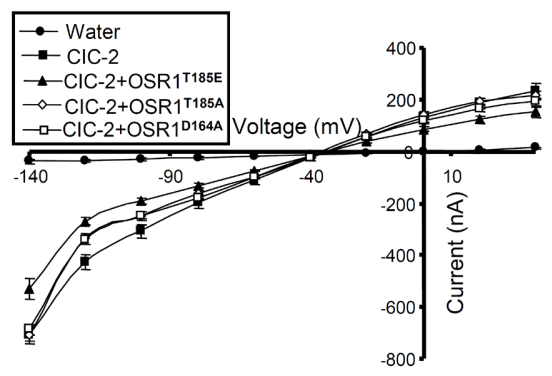

C

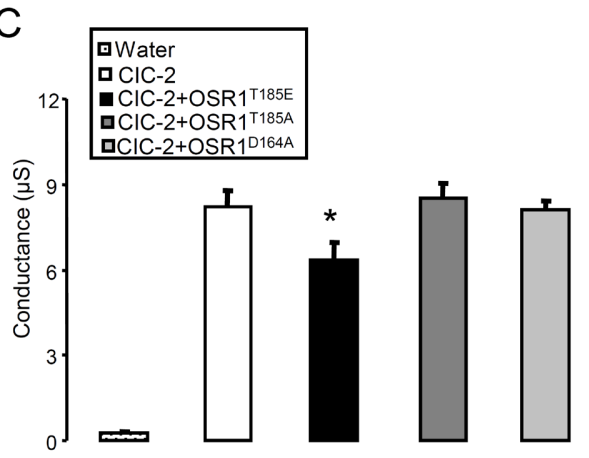

Fig. 4. Effect of expression of constitutively active OSR $1^{\mathrm{T} 185 \mathrm{E}}$, inactive OSR $1^{\mathrm{T} 185 \mathrm{~A}}$ and catalytically inactive OSR1 ${ }^{\mathrm{D} 164 \mathrm{~A}}$ on $\mathrm{Cl}^{-}$conductance in $\mathrm{ClC}$-2-expressing Xenopus laevis oocytes. A: Representative original tracings showing currents in Xenopus laevis oocytes injected with DEPC water (a), as well as in oocytes expressing ClC-2 without (b) or with additional coexpression of constitutively active OSR1 ${ }^{\mathrm{T} 185 \mathrm{E}}$ (c), inactive OSR1 ${ }^{\mathrm{T} 185 \mathrm{~A}}$ (d) and catalytically inactive OSR1 ${ }^{\mathrm{D} 164 \mathrm{~A}}(\mathrm{e})$. B: Arithmetic means \pm SEM $(\mathrm{n}=21-25)$ of the current (I) as a function of the potential difference across the cell membrane (V) in Xenopus laevis oocytes injected with water (black circles), expressing $\mathrm{ClC}-2$ alone (black squares) or expressing $\mathrm{ClC}-2$ together with constitutively active OSR1 ${ }^{\mathrm{T} 185 \mathrm{E}}$ (black triangles), inactive OSR1 ${ }^{\mathrm{T} 185 \mathrm{~A}}$ (white diamonds) and catalytically inactive OSR1 ${ }^{\mathrm{D} 164 \mathrm{~A}}$ (white squares). C: Arithmetic means \pm SEM $(n=21-25)$ of the conductance calculated by linear fit of I/Vcurves shown in B between $-140 \mathrm{mV}$ and $-80 \mathrm{mV}$ in Xenopus laevis oocytes injected with water (dotted bar), expressing ClC-2 alone (white bar) or expressing ClC-2 together with constitutively active OSR1 ${ }^{\mathrm{T} 185 \mathrm{E}}$ (black bar), inactive OSR $1^{\mathrm{T} 185 \mathrm{~A}}$ (dark grey bar) and catalytically inactive OSR1 ${ }^{\mathrm{D} 164 \mathrm{~A}}$ (light grey bar). ${ }^{*}(\mathrm{p}<0.05)$ indicates statistically significant difference to expression of ClC-2 alone.

$\mathrm{Cl}^{-}$channels further participate in the regulation of cell volume during apoptosis [5161] and SPAK/OSR1 sensitive ClC-2 activity could - at least in theory - counteract apoptotic cell shrinkage. $\mathrm{ClC}-2 \mathrm{Cl}^{-}$channels particularly impact on survival of male germ cells and photoreceptors [62].

SPAK/OSR1 sensitive ClC-2 activity may further participate in the regulation of cytosolic $\mathrm{Cl}^{-}$ activity, cell membrane potential and thus excitability of neurons [63]. ClC-2 participates in the regulation of pulmonary chloride and water secretion, a prerequisite for fetal lung development [64]. Clearly, further experiments are required to fully elucidate the physiological functions dependent on SPAK/OSR1 sensitive regulation of ClC-2.

\section{Conclusion}

SPAK and OSR1 both downregulate ClC-2 and thus contribute to the regulation of this ubiquitously expressed $\mathrm{Cl}^{-}$channel. 


\section{Kidney \\ Blood Pressure Research}

Kidney Blood Press Res 2014;39:378-387

\begin{tabular}{l|l}
\hline DOI: $10.1159 / 000355816$ & (c 2014 S. Karger AG, Basel
\end{tabular}

Publisned online: Uctober 14, 2014

www.karger.com/kbr

Fig.5. Effect of brefeldin A on ClC-2 channel activity with or without coexpression of SPAK or OSR1. A: Arithmetic means \pm SEM $(n=18-30)$ of conductance calculated by linear fit of $\mathrm{I} / \mathrm{V}$ curves between $-140 \mathrm{mV}$ and $-80 \mathrm{mV}$ in Xenopus laevis oocytes injected with ClC-2 alone (ClC-2, white bars) or expressing ClC-2 together with SPAK (black bars) prior to (left bars, 0h) and following (middle and right bars) incubation with brefeldin A $(5 \mu \mathrm{M})$ for $16 \mathrm{~h}$ or $24 \mathrm{~h}$. B: Arithmetic means \pm SEM $(n=16-30)$ of conductance calculated by linear fit of respective $\mathrm{I} / \mathrm{V}$-curves between $-140 \mathrm{mV}$ and $-80 \mathrm{mV}$ in Xenopus laevis oocytes injected with ClC-2 alone (ClC-2, white bars) or expressing ClC-2 together with OSR1 (black bars) prior to (left bars, $0 \mathrm{~h}$ ) and following (middle and right bars) incubation with brefeldin A $(5 \mu \mathrm{M})$ for $16 \mathrm{~h}$ or $24 \mathrm{~h}$. *** $(\mathrm{p}<0.001)$ indicates statistically significant difference from expression of $\mathrm{ClC}-2$ alone. \# $(\mathrm{p}<0.05)$, \#\# $(\mathrm{p}<0.01)$ and \#\#\# $(\mathrm{p}<0.001)$ indicate statistically significant difference from absence of brefeldin A.

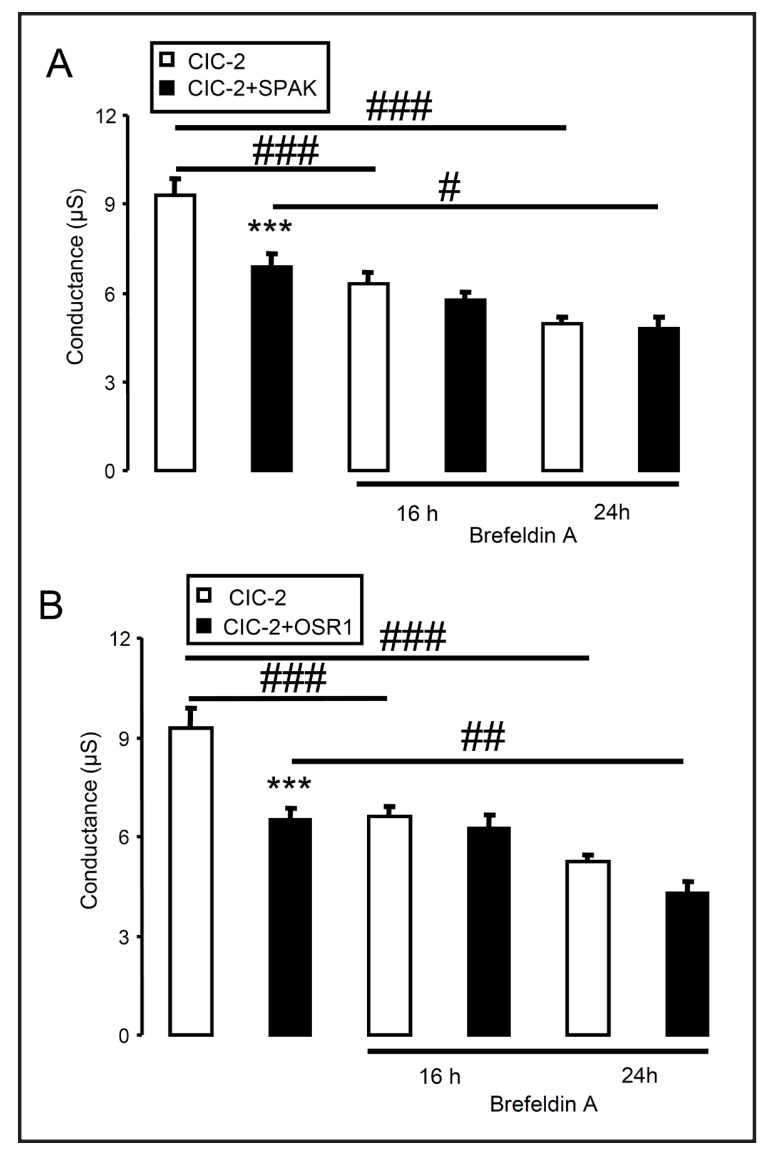

\section{Disclosure Statement}

The authors state that they do not have any conflict of interests and nothing to disclose.

\section{Acknowledgements}

The authors acknowledge the meticulous preparation of the manuscript by Sari Rübe and technical support by Elfriede Faber. This study was supported by the Deutsche Forschungsgemeinschaft, GRK 1302, SFB 773 B4/A1, La 315/13-3 and the Open Access Publishing Fund of Tuebingen University.

\section{References}

-1 Rafiqi FH, Zuber AM, Glover M, Richardson C, Fleming S, Jovanovic S, Jovanovic A, O'Shaughnessy KM, Alessi DR: Role of the WNK-activated SPAK kinase in regulating blood pressure. EMBO Mol.Med. 2010;2:63-75.

-2 Castaneda-Bueno M, Gamba G: SPAKling insight into blood pressure regulation. EMBO Mol Med 2010;2:3941.

-3 Yang SS, Lo YF, Wu CC, Lin SW, Yeh CJ, Chu P, Sytwu HK, Uchida S, Sasaki S, Lin SH: SPAK-knockout mice manifest Gitelman syndrome and impaired vasoconstriction. J Am Soc Nephrol 2010;21:1868-1877.

- Lin SH, Yu IS, Jiang ST, Lin SW, Chu P, Chen A, Sytwu HK, Sohara E, Uchida S, Sasaki S, Yang SS: Impaired phosphorylation of $\mathrm{Na}(+)-\mathrm{K}(+)-2 \mathrm{Cl}(-)$ cotransporter by oxidative stress-responsive kinase-1 deficiency manifests hypotension and Bartter-like syndrome. Proc Natl Acad Sci USA 2011;108:17538-17543. 


\section{Kidney \\ Blood Pressure Research}

Warsi/Hosseinzadeh/Elvira/Bissinger/Shumilina/Lang: SPAK and OSR1 Sensitive CIC-2

5 Villa F, Deak M, Alessi DR, van Aalten DM: Structure of the OSR1 kinase, a hypertension drug target. Proteins 2008;73:1082-1087.

6 Vitari AC, Thastrup J, Rafiqi FH, Deak M, Morrice NA, Karlsson HK, Alessi DR: Functional interactions of the SPAK/OSR1 kinases with their upstream activator WNK1 and downstream substrate NKCC1. Biochem J 2006;397:223-231.

7 Glover M, Zuber AM, O'Shaughnessy KM: Hypertension, dietary salt intake, and the role of the thiazidesensitive sodium chloride transporter NCCT. Cardiovasc Ther 2011;29:68-76.

-8 O'Reilly M, Marshall E, Speirs HJ, Brown RW: WNK1, a gene within a novel blood pressure control pathway, tissue-specifically generates radically different isoforms with and without a kinase domain. J Am Soc Nephrol 2003;14:2447-2456.

-9 Vitari AC, Deak M, Morrice NA, Alessi DR: The WNK1 and WNK4 protein kinases that are mutated in Gordon's hypertension syndrome phosphorylate and activate SPAK and OSR1 protein kinases. Biochem J 2005;391:17-24.

10 Kahle KT, Rinehart J, Lifton RP: Phosphoregulation of the Na-K-2Cl and K-Cl cotransporters by the WNK kinases. Biochim Biophys Acta 2010;1802:1150-1158.

11 Flatman PW: Cotransporters, WNKs and hypertension: an update. Curr Opin Nephrol Hypertens 2008;17:186-192.

12 Furgeson SB, Linas S: Mechanisms of type I and type II pseudohypoaldosteronism. J Am Soc Nephrol 2010;21:1842-1845.

13 Uchida S: Pathophysiological roles of WNK kinases in the kidney. Pflugers Arch 2010;460:695-702.

14 Wilson FH, Disse-Nicodeme S, Choate KA, Ishikawa K, Nelson-Williams C, Desitter I, Gunel M, Milford DV, Lipkin GW, Achard JM, Feely MP, Dussol B, Berland Y, Unwin RJ, Mayan H, Simon DB, Farfel Z, Jeunemaitre X, Lifton RP: Human hypertension caused by mutations in WNK kinases. Science 2001;293:1107-1112.

15 Achard JM, Disse-Nicodeme S, Fiquet-Kempf B, Jeunemaitre X: Phenotypic and genetic heterogeneity of familial hyperkalaemic hypertension (Gordon syndrome). Clin Exp Pharmacol Physiol 2001;28:1048-1052.

16 Capasso G, Cantone A, Evangelista C, Zacchia M, Trepiccione F, Acone D, Rizzo M: Channels, carriers, and pumps in the pathogenesis of sodium-sensitive hypertension. Semin Nephrol 2005;25:419-424.

17 Delpire E, Gagnon KB: SPAK and OSR1, key kinases involved in the regulation of chloride transport. Acta Physiol (Oxf) 2006;187:103-113.

18 Delpire E, Gagnon KB: SPAK and OSR1: STE20 kinases involved in the regulation of ion homoeostasis and volume control in mammalian cells. Biochem J 2008;409:321-331.

19 Gimenez I: Molecular mechanisms and regulation of furosemide-sensitive $\mathrm{Na}-\mathrm{K}-\mathrm{Cl}$ cotransporters. Curr Opin Nephrol Hypertens 2006;15:517-523.

20 Richardson C, Sakamoto K, de los HP, Deak M, Campbell DG, Prescott AR, Alessi DR: Regulation of the NKCC2 ion cotransporter by SPAK-OSR1-dependent and -independent pathways. J Cell Sci 2011;124:789800 .

21 Gagnon KB, Delpire E: On the substrate recognition and negative regulation of SPAK, a kinase modulating Na+-K+-2Cl- cotransport activity. Am J Physiol Cell Physiol 2010;299:C614-C620.

22 Glover M, O'Shaughnessy KM: SPAK and WNK kinases: a new target for blood pressure treatment? Curr Opin Nephrol Hypertens 2011;20:16-22.

-23 Huang CL, Yang SS, Lin SH: Mechanism of regulation of renal ion transport by WNK kinases. Curr Opin Nephrol Hypertens 2008;17:519-525.

24 Mercier-Zuber A, O'Shaughnessy KM: Role of SPAK and OSR1 signalling in the regulation of $\mathrm{NaCl}$ cotransporters. Curr Opin Nephrol Hypertens 2011;20:534-540.

25 Richardson C, Alessi DR: The regulation of salt transport and blood pressure by the WNK-SPAK/OSR1 signalling pathway. J Cell Sci 2008;121:3293-3304.

26 Pasham V, Pathare G, Fajol A, Rexhepaj R, Michael D, Pakladok T, Alesutan I, Rotte A, Foller M, Lang F: OSR1sensitive small intestinal Na+ transport. Am J Physiol Gastrointest Liver Physiol 2012;303:G1212-1219.

27 Pathare G, Foller M, Daryadel A, Mutig K, Bogatikov E, Fajol A, Almilaji A, Michael D, Stange G, Voelkl J, Wagner CA, Bachmann S, Lang F: OSR1-Sensitive Renal Tubular Phosphate Reabsorption. Kidney Blood Press Res 2012;36:149-161.

28 Pathare G, Foller M, Michael D, Walker B, Hierlmeier M, Mannheim JG, Pichler BJ, Lang F: Enhanced FGF23 Serum Concentrations and Phosphaturia in Gene Targeted Mice Expressing WNK-Resistant Spak. Kidney Blood Press Res 2012;36:355-364. 


\section{Kidney \\ Blood Pressure Research}

29 Pasham V, Rotte A, Yang WT, Zelenak C, Bhandaru M, Foller M, Lang F: OSR1-sensitive regulation of Na+/H+ exchanger activity in dendritic cells. Am J Physiol Cell Physiol 2012;303:C416-C426.

30 Delpire E, Austin TM: Kinase regulation of Na+-K+-2Cl- cotransport in primary afferent neurons. J Physiol 2010;588:3365-3373.

31 Furukawa T, Ogura T, Katayama Y, Hiraoka M: Characteristics of rabbit ClC-2 current expressed in Xenopus oocytes and its contribution to volume regulation. Am J Physiol 1998;274:C500-512.

32 Grunder S, Thiemann A, Pusch M, Jentsch TJ: Regions involved in the opening of CIC-2 chloride channel by voltage and cell volume. Nature 1992;360:759-762.

-33 Thiemann A, Grunder S, Pusch M, Jentsch TJ: A chloride channel widely expressed in epithelial and nonepithelial cells. Nature 1992;356:57-60.

34 Jentsch TJ, Gunther W, Pusch M, Schwappach B: Properties of voltage-gated chloride channels of the ClC gene family. J Physiol 1995;482:19S-25S.

35 Lang F, Busch GL, Volkl H: The diversity of volume regulatory mechanisms. Cell Physiol Biochem 1998;8:145.

36 Macri P, Breton S, Marsolais M, Lapointe J, Laprade R: Hypertonicity decreases basolateral K+ and Clconductances in rabbit proximal convoluted tubule. J Membr Biol 1997;155:229-237.

37 Pusch M, Jordt SE, Stein V, Jentsch TJ: Chloride dependence of hyperpolarization-activated chloride channel gates. J Physiol 1999;515:341-353.

-38 Stegen C, Matskevich I, Wagner CA, Paulmichl M, Lang F, Broer S: Swelling-induced taurine release without chloride channel activity in Xenopus laevis oocytes expressing anion channels and transporters. Biochim Biophys Acta 2000;1467:91-100.

39 Pakladok T, Almilaji A, Munoz C, Alesutan I, Lang F: PIKfyve sensitivity of hERG channels. Cell Physiol Biochem 2013;31:785-794.

40 Mia S, Munoz C, Pakladok T, Siraskar G, Voelkl J, Alesutan I, Lang F: Downregulation of Kv1.5 K channels by the AMP-activated protein kinase. Cell Physiol Biochem 2012;30:1039-1050.

-41 Henrion U, Zumhagen S, Steinke K, Strutz-Seebohm N, Stallmeyer B, Lang F, Schulze-Bahr E, Seebohm G: Overlapping cardiac phenotype associated with a familial mutation in the voltage sensor of the KCNQ1 channel. Cell Physiol Biochem 2012;29:809-818.

42 Hosseinzadeh Z, Bhavsar SK, Lang F: Downregulation of ClC-2 by JAK2. Cell Physiol Biochem 2012;29:737742.

43 Alesutan I, Sopjani M, Dermaku-Sopjani M, Munoz C, Voelkl J, Lang F: Upregulation of Na-coupled glucose transporter SGLT1 by Tau tubulin kinase 2. Cell Physiol Biochem 2012;30:458-465.

44 Hosseinzadeh Z, Dong L, Bhavsar SK, Warsi J, Almilaji A, Lang F: Upregulation of peptide transporters PEPT1 and PEPT2 by Janus kinase JAK2. Cell Physiol Biochem 2013;31:673-682.

45 Almilaji A, Munoz C, Hosseinzadeh Z, Lang F: Upregulation of Na+,Cl(-)-coupled betaine/gamma-aminobutyric acid transporter BGT1 by Tau tubulin kinase 2. Cell Physiol Biochem 2013;32:334-343.

-46 Bogatikov E, Munoz C, Pakladok T, Alesutan I, Shojaiefard M, Seebohm G, Foller M, Palmada M, Bohmer C, Broer S, Lang F: Up-regulation of amino acid transporter SLC6A19 activity and surface protein abundance by PKB/Akt and PIKfyve. Cell Physiol Biochem 2012;30:1538-1546.

-47 Almilaji A, Szteyn K, Fein E, Pakladok T, Munoz C, Elvira B, Towhid ST, Alesutan I, Shumilina E, Bock CT, Kandolf R, Lang F: Down-regulation of Na/K+ atpase activity by human parvovirus B19 capsid protein VP1. Cell Physiol Biochem 2013;31:638-648.

48 Dermaku-Sopjani M, Almilaji A, Pakladok T, Munoz C, Hosseinzadeh Z, Blecua M, Sopjani M, Lang F: Downregulation of the Na-coupled phosphate transporter NaPi-IIa by AMP-activated protein kinase. Kidney Blood Press Res 2013;37:547-556.

-49 Lang F, Foller M, Lang K, Lang P, Ritter M, Vereninov A, Szabo I, Huber SM, Gulbins E: Cell volume regulatory ion channels in cell proliferation and cell death. Methods Enzymol 2007;428:209-225.

-50 Ritter M, Woll E, Waldegger S, Haussinger D, Lang HJ, Scholz W, Scholkens B, Lang F: Cell shrinkage stimulates bradykinin-induced cell membrane potential oscillations in NIH 3T3 fibroblasts expressing the ras-oncogene. Pflugers Arch 1993;423:221-224.

51 Elinder F, Akanda N, Tofighi R, Shimizu S, Tsujimoto Y, Orrenius S, Ceccatelli S: Opening of plasma membrane voltage-dependent anion channels (VDAC) precedes caspase activation in neuronal apoptosis induced by toxic stimuli. Cell Death Differ 2005;12:1134-1140. 


\section{Kidney \\ Blood Pressure Research}

52 Lang F, Shumilina E, Ritter M, Gulbins E, Vereninov A, Huber SM: Ion channels and cell volume in regulation of cell proliferation and apoptotic cell death. Contrib Nephrol 2006;152:142-160.

53 Myssina S, Lang PA, Kempe DS, Kaiser S, Huber SM, Wieder T, Lang F: Cl- channel blockers NPPB and niflumic acid blunt $\mathrm{Ca}(2+)$-induced erythrocyte 'apoptosis'. Cell Physiol Biochem 2004;14:241-248.

54 Okada Y, Maeno E: Apoptosis, cell volume regulation and volume-regulatory chloride channels. Comp Biochem Physiol A Mol Integr Physiol 2001;130:377-383.

55 Okada Y, Maeno E, Shimizu T, Manabe K, Mori S, Nabekura T: Dual roles of plasmalemmal chloride channels in induction of cell death. Pflugers Arch 2004;448:287-295.

56 Porcelli AM, Ghelli A, Zanna C, Valente P, Ferroni S, Rugolo M: Apoptosis induced by staurosporine in ECV304 cells requires cell shrinkage and upregulation of Cl- conductance. Cell Death Differ 2004;11:655662.

57 Shimizu T, Numata T, Okada Y: A role of reactive oxygen species in apoptotic activation of volume-sensitive Cl(-) channel. Proc Natl Acad Sci USA 2004;101:6770-6773.

58 Souktani R, Berdeaux A, Ghaleh B, Giudicelli JF, Guize L, Le Heuzey JY, Henry P: Induction of apoptosis using sphingolipids activates a chloride current in Xenopus laevis oocytes. Am J Physiol Cell Physiol 2000;279:C158-C165.

-59 Szabo I, Lepple-Wienhues A, Kaba KN, Zoratti M, Gulbins E, Lang F: Tyrosine kinase-dependent activation of a chloride channel in CD95-induced apoptosis in T lymphocytes. Proc Natl Acad Sci USA 1998;95:61696174.

60 Wei L, Xiao AY, Jin C, Yang A, Lu ZY, Yu SP: Effects of chloride and potassium channel blockers on apoptotic cell shrinkage and apoptosis in cortical neurons. Pflugers Arch 2004;448:325-334.

61 Zuo W, Zhu L, Bai Z, Zhang H, Mao J, Chen L, Wang L: Chloride channels involve in hydrogen peroxideinduced apoptosis of PC12 cells. Biochem Biophys Res Commun 2009;387:666-670.

-62 Bosl MR, Stein V, Hubner C, Zdebik AA, Jordt SE, Mukhopadhyay AK, Davidoff MS, Holstein AF, Jentsch TJ: Male germ cells and photoreceptors, both dependent on close cell-cell interactions, degenerate upon ClC-2 Cl(-) channel disruption. EMBO J 2001;20:1289-1299.

63 Staley K, Smith R, Schaack J, Wilcox C, Jentsch TJ: Alteration of GABAA receptor function following gene transfer of the CLC-2 chloride channel. Neuron 1996;17:543-551.

64 Blaisdell CJ, Edmonds RD, Wang XT, Guggino S, Zeitlin PL: pH-regulated chloride secretion in fetal lung epithelia. Am J Physiol Lung Cell Mol Physiol 2000;278:L1248-1255. 